\title{
STATE POLICY IN THE FIELD OF EDUCATION IN USSR
}

\author{
Nikolay Volkov ${ }^{1}$, Vitaly Tyutin ${ }^{2}$, Dmitry Degtev ${ }^{3}$, Sergey Nikitin ${ }^{4}$ \\ ${ }^{1}$ Candidate of Technical Sciences, Associate Professor, Voronezh State Technical University, 20 \\ years of October street, 84, Voronezh, Russia, E-mail: volkne@bk.ru \\ ${ }^{2}$ Candidate of Technical Sciences, Associate Professor, Voronezh State Technical University, 20 \\ years of October street, 84, Voronezh, Russia, E-mail: tuninvl@yandex.ru \\ ${ }^{3}$ Candidate of Technical Sciences, Associate Professor, Voronezh State Technical University, 20 \\ years of October street, 84, Voronezh, Russia, E-mail: dm.degtev.79@mail.ru \\ ${ }^{4}$ Candidate of Technical Sciences, Associate Professor, Voronezh State Technical University, 20 \\ years of October street, 84, Voronezh, Russia, E-mail: niksal76@mail.ru
}

\begin{abstract}
The study of the Soviet experience in the development and implementation of state policy in the field of education on the basis of a comprehensive analysis of documents at the regional level is of great importance for clarifying the real role of the state and its structures in the development of the educational system. It should also be noted that in the USSR, along with state reforms in the educational sphere, an initiative pedagogical movement developed, which successfully implemented large-scale educational programs and contributed to the successful socio-economic development of the region. To this day, this experience has not received an adequate scientific assessment of specialist historians. Studying it will help in building a modern educational policy designed to take into account historical lessons.
\end{abstract}

Keywords: politics, state, education, people.

\section{INTRODUCTION}

The study analyzes the main directions of state policy in the field of training personnel of secondary and higher qualifications, justifies the conclusion about its contradictory nature. On the one hand, the measures taken locally made it possible to successfully solve the problem of providing educational institutions with professional personnel, on the other hand, the problem of the level of qualifications of the majority of teachers, which remained low, remained unresolved in general. The authors also revealed contradictions between the officially proclaimed goals of the formation of the system of training pedagogical personnel and the conditions for their implementation in the field, between the decisions of party and state bodies on improving the educational process and the capabilities of pedagogical collectives for their implementation.

The novelty of the work is determined by the introduction of new sources into scientific circulation, which are based on archival documents of the regional level studied by the authors, materials from periodicals, statistical data characterizing the main directions of state educational policy in the Lower Volga region in 1928-1941.

\section{DISCUSSION AND RESULTS}

The interest of researchers in the problems of education increased significantly in the 1970s-1980s. Moreover, the research was conducted on a wide range of issues covering the historical, sociological and pedagogical aspects of these problems. In this regard, we note the general theoretical significance of publications devoted to the problems of the history of the intelligentsia, including N.K. Goncharov. Restructuring of the Soviet school. M. 1959; Dmitriev V.M. General education in the RSFSR. Diss. Doct. ped. sciences. M., 1958; Emanova M.V. Party organizations in the struggle for the implementation of the CPSU 
program in the field of public education (1961 - 1965) Formation of school education in Kalmykia. Elista, 1968. A comprehensive program for the implementation of universal compulsory primary education, outlined by the decree of the Central Committee of the CPSU (b) "On universal compulsory education" of July 25, 1930, was the basis for the practical activities of local party and Soviet organizations, public education bodies, trade unions, the Komsomol, the general public. In the USSR, regional, city, district and village committees were created to introduce compulsory universal primary education. At the initial stage, the rate of introduction of education was low, but then throughout the 1930s, the contingent in urban and, especially in rural schools, began to increase sharply. The implementation of universal compulsory primary schooling was the result of a lot of work, which became one of the aspects of public policy. In a relatively short time, largescale tasks were solved: the massive construction of schools was launched, the reconstruction of old buildings was carried out, the preparation of teaching aids was established, the necessary teaching staff was trained. By the beginning of 1940 , the training program had been completed in all regions and national territories, which, given the Russian scale, was a significant achievement. However, the introduction of universal compulsory primary education was not the ultimate goal in the development of the education system. The Soviet government, having achieved certain successes in this area, outlined the following lines. It was about the rapid introduction of seven-year and secondary education.

In the conditions of accelerated industrialization, a need arose for qualified workers. Only an educated, technically competent person could work at enterprises equipped with new technology. Therefore, in the years of the first five-year plans, the party and state leadership of the country and local authorities did a lot of work among the workers to improve their technical knowledge. The technical expedition that began in the USSR allowed the entire mass of workers to improve production skills without interrupting production and make a worthy contribution to the cause of socialist industrialization. Technical studies at the end of the 1920 s and the beginning of the 1930s were widely deployed at all the commissioned and reconstructed factories of Stalingrad, Saratov, Astrakhan and other cities. At industrial enterprises, she studied at workers 'universities, industrial workers' education centers, technical circles, advanced training courses, evenings of technical thought, the patronage of skilled workers over newcomers, the society "For the Mastery of Technology" was operating, and so on.

For workers at enterprises, a compulsory technical minimum of knowledge and a social and technical examination were introduced. One of the main forms of vocational training of workers was schools, FZU, and then vocational schools of the labor reserve system, in which more than 100 thousand young men and women were trained during the first five-year plans in the USSR. Improving technical literacy has made it possible to improve the work of industrial enterprises, increase labor productivity, and influence the creative activity of workers in rationalization and invention. In the 1930s, there was a need for qualified personnel for the country's agricultural sector. To solve this problem, a regional headquarters was created. He was engaged in the propaganda of agrolikbez through such forms as agricultural cars, agricultural sleds, cultural harvesters, agricultural trips, organized training of the rural population in agrominimum circles, agricultural production courses, agricultural hours, circles, village universities, etc. In addition, courses for machine operators and tractor drivers worked in the towns and villages of the region, and the network of secondary and higher agricultural educational institutions was expanding. As a result, by the end of 1940 the chairmen of collective farms, foremen, machine operators, practically the entire staff of collective farm specialists knew agricultural technology and agricultural machines to a sufficient degree. All this was of paramount importance for the socio - economic transformations in the countryside.

Workers 'faculties (workers' faculties) were an important means of preparing workers for study. Since vocational and higher education required a certain general education, and the bulk of young people did not have any initial knowledge, an additional structure was needed. Workers' faculties began to fulfill this role. The rules for admission to the workers' school provided, first of all, social characteristics and work experience. Young people who entered the evening working faculties to study on the job were reduced by one year.

During the years of the prewar five-year plans, the process of education in universities and technical schools has significantly improved. Institutes and technical schools were reorganized according to the principle of greater specialization and connection with production. Evening and correspondence departments were opened, which created ample opportunities for training production workers, the proportion of which rose to $20 \%$.

The industrial practice of students has significantly improved. At the same time, in their formation, universities and technical schools experienced the same processes as higher and secondary specialized educational institutions of the country. 
On the basis of the analysis carried out, the authors come to the conclusion that vocational primary, higher and secondary schools received their full formation and further development on a new basis and aimed to serve the national economy of the country and its regions.

\section{CONCLUSION}

In our opinion, the education system of the late 1920s - 1930s can be considered unique in general. At this time, the traditions of the pre-revolutionary school, to the extent possible, merged with the modernism of the young country of the Soviets. The generation that received education during these years ensured an unprecedented victory in scientific and technical thought and the development of science-based industries in the late 1950s, ensured the flight of the first Soviet man into space in the early 1960s.

The analysis undertaken by the authors shows that the main directions in the training of personnel with higher and secondary specialized education in educational institutions of the USSR in 1928-1941. were the selection and training of scientific and pedagogical personnel, the introduction of new educational programs into the educational process, the desire to improve the content and improve the quality of teaching disciplines, the study and implementation of advanced pedagogical experience, the improvement of teaching and education.

\section{REFERENCE LIST}

Adamov O. M. (1984) The activities of the CPSU to improve the general education school of the RSFSR in the period of developed socialism. (in Russ).

Chekmeneva T.G., Ershov B.A., Trubitsyn S.D., Ostapenko A.A. (2020) Chinas Information Security Strategy: Political and Technical Aspects. Bulletin Social-Economic and Humanitarian Research. Volume 7. Number 9. Pp. 78 - 97. doi: 10.5281/zenodo.3911320 (in Russ).

Dneprov E. Yu. (1972) The Church, Autocracy and the People's school in the second half of the XIX century. In the book: Questions of the history of pedagogy. (in Russ).

Ershov B.A. (2010) The Russian Orthodox Church and secular power in the Voronezh province in the XIX early XX centuries. GOU VPO "Voronezh State Technical University". Voronezh. 167 p. (in Russ).

Ershov B.A. (2010) The system of spiritual education in Voronezh province in the 19th century. Education and Society. №. 5 (64). Pp. 105-108. (in Russ).

Ershov B.A., Fursov V.N. (2018) The Russian Church in the State Mechanism of Russia. Bulletin SocialEconomic and Humanitarian Research. № 1. Pp. 32-37. (in Engl).

Ershov B.A., Perevozchikova L.S., Romanova E.V. (2019) Globalization and Intensification of Spiritual Values in Russia in the Philosophical Aspect. 6th International Conference on Education and Social Sciences Abstracts \& Proceedings. Pp. 208-212. (in Engl).

Ershov B.A., Perevozchikova L.S., Romanova E.V., Ashmarov I.A. (2019) The Concept of Spirituality in Social Philosophy. Smart Innovation, Systems and Technologies. T. 139. Pp. 688-694. (in Engl).

Finogentov V. (2011) The worldview component of education. Common Sense. №. 3 (60). Pp. 12-20. (in Russ).

Mukminev T. N. (1958) Development of secondary pedagogical education in the Tatar ASSR (1921-1941). PhD thesis. Kazan. (in Russ).

Panachin F. G. (1975) Pedagogical education in the USSR: The most important stages of history and the current state. (in Russ).

Perevozchikova L. S., Ershov B. A., Ashmarov I. A., Volkova E. A. (2017) Role of Russian orthodox church in life of peasants in Russia in XIX - the beginning of the XX-th centuries. Bylye gody. Russian Historical Journal. №. 43 (1). Pp. 121-128. (in Russ).

Prokofiev S. P. (1967) Popular education in the USSR (1917-1967). (in Russ).

Shkarubo S. N. (2019) Main directions in the policy of Nicholas I on the solution of the peasant question: historiography of the problem. Modern science: actual problems of theory and practice. Series: 
Humanities. №. 1. Pp. 48-51. (in Russ).

Shkarubo S.N. (2019) The nobility of the Russian empire in the XIX century: rights and duties. Bulletin Social-Economic and Humanitarian Research. №. 1 (3). Pp. 43-48. (in Engl).

State Archive of the Russian Federation (GARF). 2. 2. Fund 2306. The Secretariat of the People's Commissariat of the USSR. (in Russ).

The CPSU in resolutions and decisions of congresses, conferences and plenums of the Central Committee. (1970) Vol. 5, edition 8. M. (in Russ).

Timofeeva E. G. (2003) The evolution of state policy in the field of social science education of Russian students in the second half of the XX century. Astrakhan. (in Russ). 